\title{
Developing a Mixed Method for Testing a Theory on Spatial Aesthetics
}

\author{
Agnese Sofija Kusmane, Latvia University of Life Sciences and Technologies
}

\begin{abstract}
The goal of this article is to find a mixture of methods to test a theory on spatial aesthetics. The theory in question is based on findings in evolutionary aesthetics and it states that there are four categories of spaces, both, urban and natural, each having a particular size measurable in meters. Besides that humans attach a certain level of preference to each of these categories. Theoretically a sufficient amount of mystery and legibility elements can improve the preference. As literature suggests the most appropriate way to test a theory is to carry out semi-structured interviews in order to find relevant information that extends and confronts the theoretical frame. In situ interviews with the inhabitants of three residential areas in Riga were carried out to test the above described theoretical construct. The aim of the interviews was to test the theory in three relevant points: perceived size of a scene, preference of a scene and the presence of mystery and legibility elements in a scene. A pilot study has shown that the first two of the points received sufficient answers in the interviews. Yet, the third one did not obtain enough information for further analysis. To fix this deficit an expert visual investigation is carried out as a complementary method to the discursive interview analysis executed before. Expert visual investigation means that the researcher investigates the objects mentioned or showed at by the interviewees in the attempt to find any hints to the presence of legibility and mystery elements in them. This method permits to escavate information on leginbility and mystery from the interviews by using the expert as an interpreter. The article questions the possibility to receive relevant information from the interviewee on very specific, theoretical concepts that are not common knowledge. This paper proposes to use a mixed method in order to completely tackle the issues of such a specific interest.
\end{abstract}

Keywords: urban space, spatial aesthetcis, semi-structured interviews, mixed method

\section{Introduction}

In a theory of environmental psychology spaces of particular sizes and configuration are preferred over the spaces that do not have the sizes and configurations $[1 ; 5 ; 13]$. Depending on size and proportion, spaces are grouped in four different categories. The open-undefined space is highly disliked, enclosed space and blocked views are not preferred, too. Whereas spaces belonging to the category spacious-well-structured are liked by humans [8]. It has been established in our previous research that not only walls of the buildings as traditionally proposed, but mainly smaller objects like trees, benches or roads are able to serve as a border of perceived urban space and thus determine its size, elements and according category [10]. Moreover, we have argued that a higher number of legibility and mystery elements impact the preference of a space disliked space can become a tolerated one if there is a sufficient number of these elements [10]. Mystery is a type of prospect - the opportunity to see into the environment - which promises more information into comparison to what is visible from the current stand point if one walks into this prospect. Legibility is type of refuge - an opportunity to hide and see a part of a space not fully visible from the current stand point.

Until now we have mainly emphasised the role of the in situ interviews in testing the above described theoretical assumptions. Semi-structured interviews brought a lot of material on size and preference of space. Interviews also implicated that the inhabitants see and evaluate such spatial elements as mystery and legibility, even though they never mentioned them directly. Luck of such direct reference shows that one method only - the interviews - is not sufficient to acquire all the needed information. The goal of this paper is to describe a complementary method that was used to utilise the information collected via interviews in order to gain understanding on how humans perceive legibility and mystery elements.

\section{Materials and Methods \\ Deficits of Collected Materials}

The general aim of my research is to contribute to the discussion about evaluation of spatial aesthetics. Scientist of environmental psychology offer in few papers metric information on most preferred spaces, both, yards and streets $[1 ; 5 ; 13]$. We have assembled this metric information and calculated the missing values. As a result new Model of Measurements of Spatial Aesthetics was established [9]. This theoretical model serves as a base to evaluate every urban space as it is formed by the walls of buildings: to determine its category by analysing its wall-to-wall size and presence of mystery and legibility elements. The utilistion of this approach has already been described [10]. Yet, since the model was established on theory based on ex situ collected empirical data, it was decided to carry out semi-structured interviews to test this theory. Closer information on the choice of interview method is given elsewehre [9]. 
A small pilot-study carried out in Riga in 2014 discovered that semi-structured interviews do provide a large amount of relevant information. The inhabitants in the interviews talked about particular scenes and also indicated were the yard or street in question had its borders. Mapping the interviews is known to be a handy tool for imagining the size of the space someone describes [12]. Such maps were executed. Also the reported preference of each space was mapped. Such maps were then compared to the previously created maps that used Model of Measurements of Spatial Aesthetics. Every scene - a yard or a street - was depicted on an aerial photography with two layers. The first layer showed the size and configuration of the space as predicted by theoretical approach. The second one - the size and the preference of the scene as described by the inhabitants. There was enough information in these two layers to realize that they show a difference in perceived size and preference of urban space. Comparing theoretical and perceived sizescomponent relevant for detecting a category - was possible. Yet, the crucial element for understanding the preference, i.e., the presence of mystery and legibility elements was not clear.

The problem that the interviews did not tackle inhabitants did not address either mystery, or legibility issues directly. It was established that decoding interviews is not enough. In the case of this research the problem was not the usual lack of so called data saturation or sample size of semistructured interviews $[3,4]$. The deficit seemed to be impossibility to test the theory by discursively analyzing a qualitative interview data only, since inhabitants interviewed were layman, who were not familiar with the concepts of legibility and mystery. I decided to purposefully not ask about these concepts, since it would have pushed people into answering out of mere willingness to help. Such data would be "positively misleading" [15].

\section{Finding Complementary Method}

The debate on usage of mixed method in humanities is not new anymore. Two types of data collection procedures are a classical example of mixed method [2;14]. It truly seems that using a supplementary approach next to discursively analyzing the interview material does prove the understanding of the object of research - spatial aesthetics. Thus, the question is relevant - how else data can be collected from the interviews in order to produce meaningful results.

The interviews provided lots of material which proves that humans think in the terms of legibility and mystery. Inhabitants talk about the need for better visibility at the same time staying unnoticed or advantages of seeing further than the current space provides. The former is a description of legibility, the latter - of a mystery. The most adequate way to preserve the information given by the inhabitants and extract the needed knowledge at the same time is a supplementary visual investigation of the space. It was conducted by the researcher.

In short, another method was utilized - expert visual investigation, in which data collection was based on interviews, yet, the expert researcher took a large role in interpretation of this data. The material objects mentioned in interviews such as "trees", "playground", "road" etc. that seemed relevant in terms of determining size or preference were written down in a form of a scripts. Similar objects were grouped in one script. For instance, all the interviews that mentioned trees in a particular scene were registered in one script etc.

The researcher then examined scenes yet for another - third time. Every scene which was labelled with "trees", for instance, received a detailed description of the trees in the scene. For example, how many trees are there? What kind of trees are there? How old are the trees? Are trees standing singularly or forming groups? What is the form of trees? What is the length of trees? What is the trunk radius? Can this tree be considered an element producing mystery or legibility? The same procedure was applied to other material objects that interviewees indicated as the ones creating border of a space at hand or being relevant for the like or dislike.

Such an approach where the researcher is interpreting the material objects into prospects and refuges has already been used before. It is especially popular in environmental psychology $[6 ; 11 ; 16]$. But also art and architectural historian Hildebrand has published few works where he served as an expert and explained the built environments from this point [7]. Yet, the important innovation is that the proposed expert visual investigation method is selecting for the analysis only those objects that are named by the interviewees.

\section{Results and Discussion}

By carefully analyzing the physical objects mentioned by the interviewees a new empirical data appeared that gave information on how objects such as trees, elevations, playgrounds, benches, also walls etc. contribute to perceiving urban spaces in terms of the presence of mystery and legibility in them. For instance, positive mentioning of small elevations of earth can be brought in connection with legibility, if the interviewee is referring to such an elevations as points where the yard can be safely observed from. To the best of my knowledge the interviews have never been used before as the description of relevant objects in nature that determine legibility and mystery elements. Thus, there is no comparison to the previous research available. 


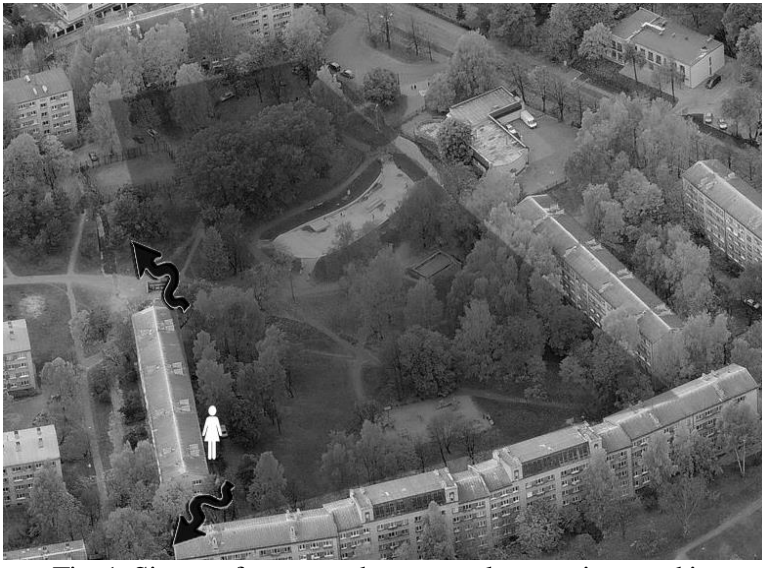

Fig. 1. Size, preference and mystery elements in a yard in Āgenskalna priedes as estimated by visual analysis. The size of the yard is shown by dark field. Black arrows with white outline show mystery elements formed by gaps between buildings. Human symbol shows the standpoint [created by the author]

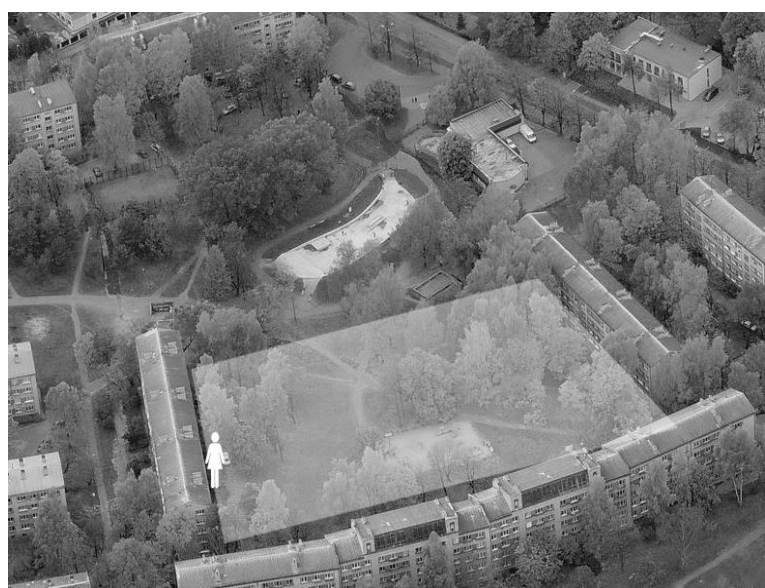

Fig. 2. Size and preference of a yard in Āgenskalna priedes as estimated by the interviewees. The white field determines the borders of the space that extends "until the trees", and some interviewees call it "their yard." The light color indicates that the interviewees tolerated the yard [created by the author]

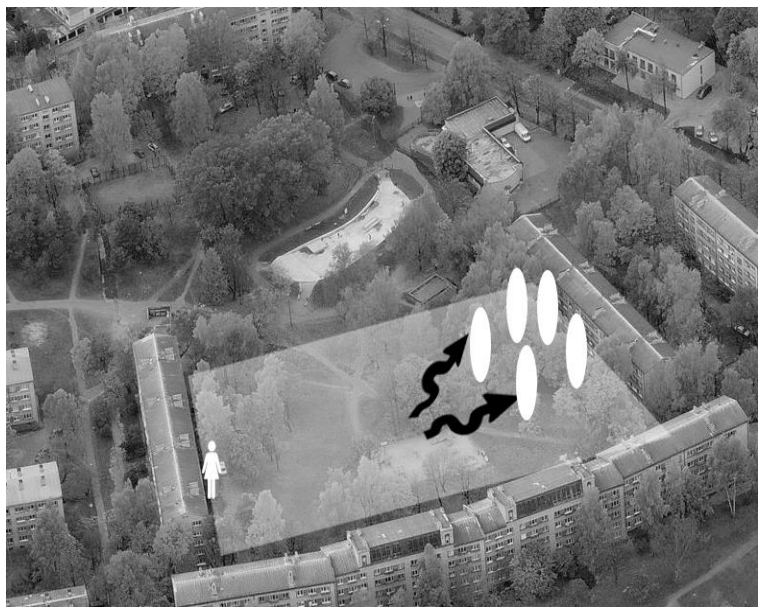

Fig. 3. Mystery elements and legibility elements in a yard in Āgenskalna priedes as estimated by expert visual investigation. Ellipses - demarcate the trees with low-growing branches that are legibility elements. Black arrows show the mystery elements that are created by the "coulisses" formed by trees. The human symbolizes the standpoint. The white field - the perceived size of the yard as indicated by the interviewees [created by the author]
I will illustrate my findings with images. Advantages and disadvantages of every method used thus are displayed. Yet, the focus of this chapter is placed on explaining the benefits of the visual expert investigation method.

In the Figure 1 an area in the residential district Agenskalna priedes is depicted. The demarcated (dark) area here is the space as estimated by the researcher using Model of Measurements of Spatial Aesthetics based on theoretical findings. It is a visual analysis method that evaluates the space as formed by the walls of the surrounding houses. The image also shows 2 mystery elements that walls create and that are visible from standpoint from which the analysis is done. This theoretical approach proposes no legibility elements in this scene. The area measures are $210 \times 140 \times 210 \times 90 \mathrm{~m}$, the surrounding buildings are $14 \mathrm{~m}$ high. The space is disliked according to the theory, hence, the dark color of the demarcated area.

The image 2 shows the same yard, yet, the demarcated area (light) is much smaller than in the Figure 1. This smaller space is the size of the yard as indicated by the inhabitants in the interviews that took place from the identical stand point as the visual analysis. The interviewees admitted, that the borders of the yard are formed by the groups of trees that are in a close proximity to the interviewee at the moment of interview; the size of this space is $70 \times 140 \mathrm{~m}$ large, the heights are $17 \mathrm{~m}$ since the tallest trees are of this size. The prospects and refuges were not mentioned in the interviews directly. The yard is reported as tolerated, hence, the light color of the area in the Figure 2.

Figure 3 depicts the results of expert visual investigation with the focus on trees. Expert visual investigation concentrated on the following objects: there are three groups of trees in the yard, yet, the inhabitants constantly refer to the largest one as being the boarder of the yard space. This group is formed of chesnuts (Castanea), maples (Acer) and lime (Tilia). There are ca. 5 older, larger trees in it, they possess low growing branches. The rest of the trees are either young and thin or do not have low growing branches. This group which demarcates the space reffered to as "their yard" by some inhabitants is formed up of volumes of dense folliage and void. Such composition ensures that this group of trees is perceived as a coulise setting.

In researcher's opinion the trees with low growing branches can be interpreted as a legibility - if one climbs these trees then a better view to a space not visible from a currant viewpoint is achieved and safety is increased. Thus this group of trees alone creates 5 elements of legibility. Whereas the composition of trees in coulisse setting adds at least 2 elements of mystery as it provides prospects into the space that is anticipated, but not visible from the current stand point. 


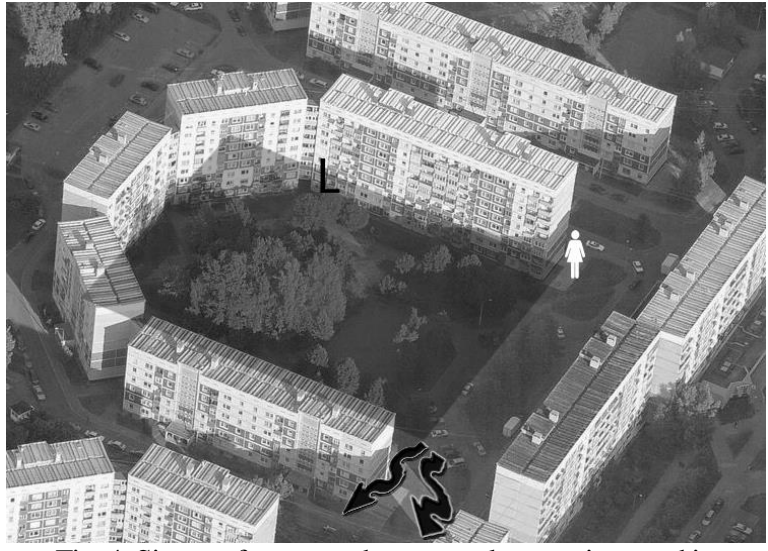

Fig. 4. Size, preference and mystery elements in a yard in

Zolitūde as estimated by visual analysis. Black arrows with white outlines show mystery elements that are formed by the gaps between buildings. "L" - legibility element created by a niche in the facade. The field colored in a dark color demarcates the size of the yard, which is theoretically disliked. The human symbolizes the standpoint [created by the author]

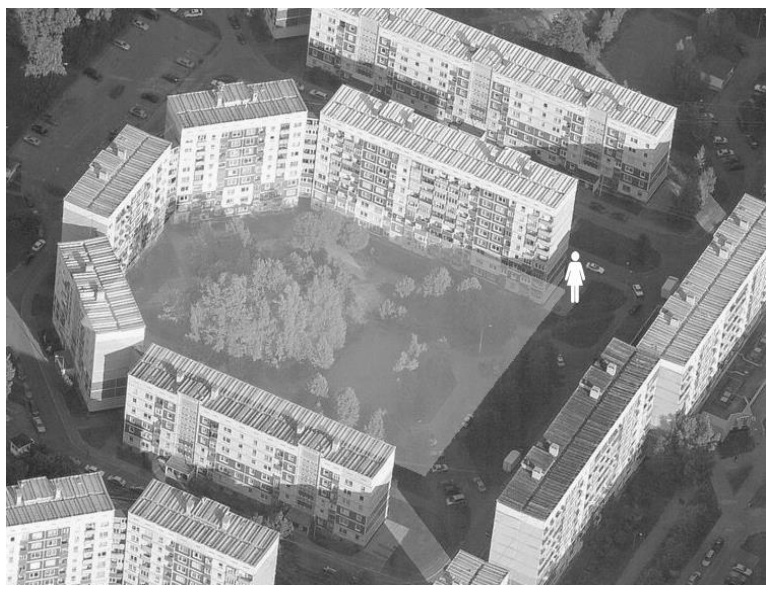

Fig. 5. Size and preference of a yard in Zolitūde as estimated by the interviewees. The white field shows the size of the yard.

The light color of this field indicates that interviewees tolerated the yard [created by the author]

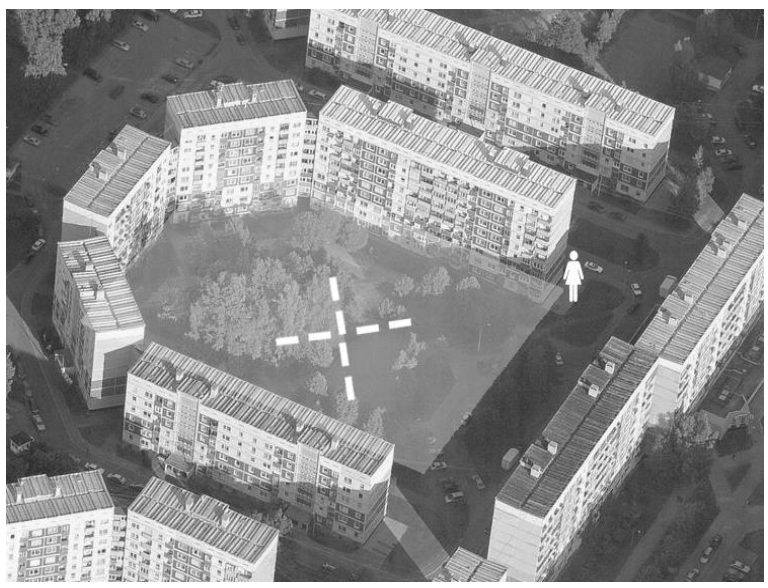

Fig. 6. Legibility elements in a yard in Zolitūde as estimated by expert visual investigation. Rectangues - demarcate the missing benches that grouped together are 4 legibility elements.

The human symbolizes the standpoint. The white field - the perceived size of the yard as indicated by the interviewees [created by the author]
The inhabitants who mentioned trees as a demarcation object in this rather large space adimtted liking their yard. According to theory large spaces with sufficient amount of legibility and mystery elements are tolerated. Hence, it can be estimated that also in reality enlarged amount of these elements plays a relavant role in liking of an open, undefined space that this yard belongs to also after considering the decrease of its size. It can be also expected that the mystery elements that are formed by the walls also play a role in the perception (see mystery elements in Figure 1). If they are added to the mystery and legibility elements created by trees, then there can be 4 mystery elements and 5 legibility elements counted in the scene.

Another example stems from Zolitūde residential area. Here the space of $110 \times 120 \mathrm{~m}$ which is bordered by the buildings that are $26 \mathrm{~m}$ high is considered to be unliked by theoretical approach. An areal view of this yard can be seen in Figure 4. Here the theoretical size, i.e., the size of the space detected by visual analysis that is measured from wall to wall and from wall to street of this yard is demarcated. Also two elements of mystery and one element of legibility that are created by the walls and a niche accrodingly are marked. The yard that belongs to open, undefined category is considered to be theoretically disliked, hence, it has dark color in the image. $80 \%$ of the space is covered by trees.

Figure 6 demonstrates the size of the yard, as it is perceived by the inhabitants. In this case the theoretical and the reported sizes are equal. The yard is evaluated as tolertated by inhabitants, hence, the light color of the field in the image Also in this case the inhabitants do not talk directly about prospects and refuges or lefibility and mystery elements.

Yet, after carefully analysing the utterances of inhabitats, some information on desired amount of those elements can be detected by expert visual investigation. Figure 6 demonstrates these findings. Benches play a decisive role here. An interview revealed that the yard used to be more liked. The reson for the decrease in prefference is the removal of benchhes some years ago.

Singular benches can be interpreted as a refuges since they provide some enclosure and offer some height to elevate oneselve in case of a danger. Whereas a group of benches can be interpreted as legibility: compounded in one yard they form a space of their own, especially if a circle of friends use them, forming a group. Such compound, if large enough, can provide an opportunity to see a part of space not visible from the stand point, which is used during the interview. There are 4 legibility elements formed by benches. Legibility amount is equal to the amount of compartments formed by two corssing rows of these objects. Benches can not form a prospect or mystery for that matter. 


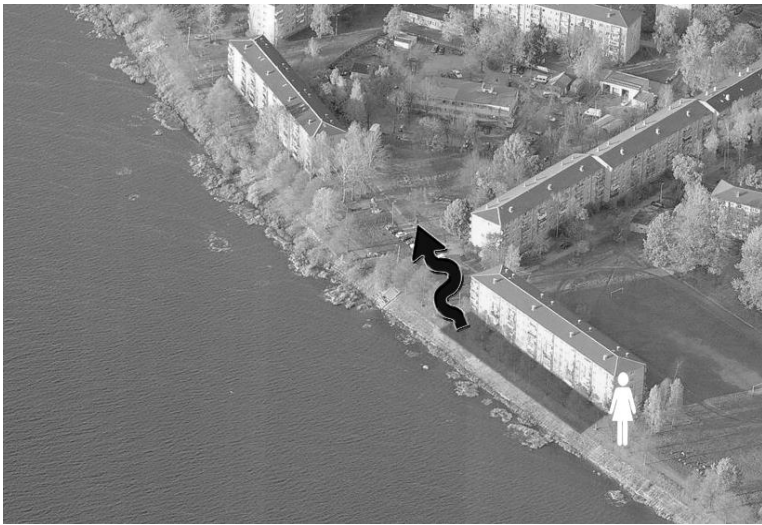

Fig. 7. Size, preference and mystery elements in a yard in Kengarags as estimated by visual analysis.

Black arrow with white outline shows the mystery element. The human symbolizes the standpoint. The dark field demarcates the size of the yard as it is detected by visual analysis.

This yard it theoretically disliked [created by the author]

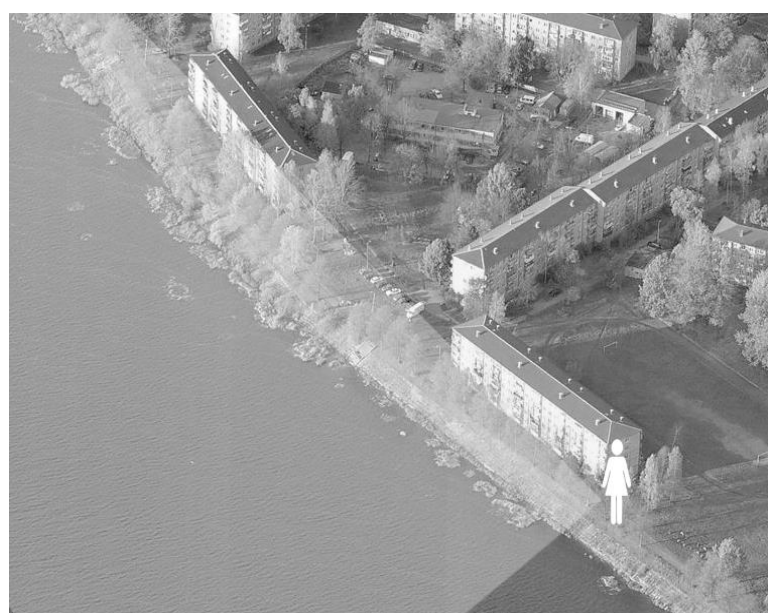

Fig. 8. Size and preference of a yard in Kengarags as estimated by the interviewees. The white large field shows the size of the yard as indicated by the interviewees.

The scene is liked, hence, the light color of the field. The human symbolizes the standpoint [created by the author]

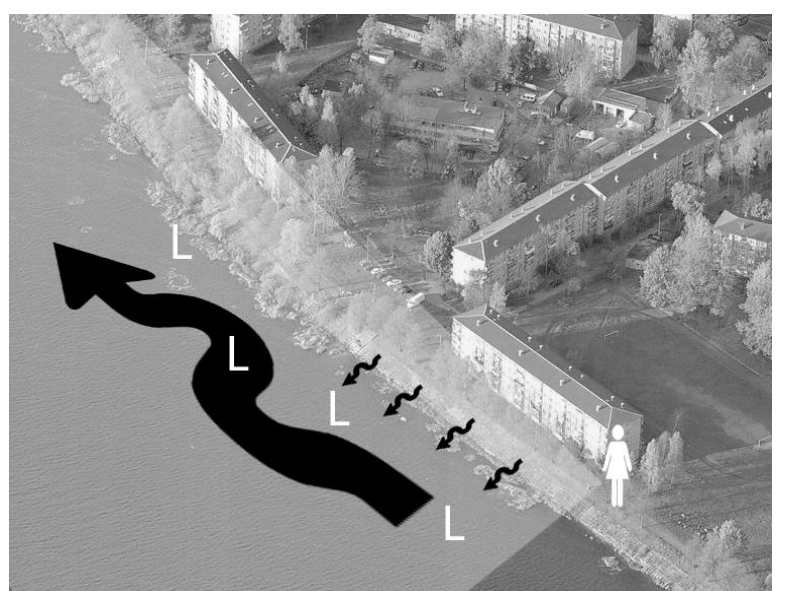

Fig. 9. Mystery and legibility elements in a yard in Agenskalna priedes as estimated by expert visual investigation.

White "L" show legibility elements formed by the river.

Black arrows symbolize the mystery elements formed by the water and slope. The human symbolizes the standpoint.

The white field - the perceived size of the yard as indicated by the interviewees [created by the author]
Moreover, it can be assumed that the mystery and legibility elements formed by walls (see Figure 4) can be added to the legibility elements created by benches. Thus there are five legibility elements and two mystery elements. An assumption can be done: that open, undefined space - a category that the space of this yard belongs to - improved with numerous legibility elements can become tolerated in reality.

The last example describes the perception of large water features such as river. In the figure 7 a scene in the residential area Kengarags is demonstrated. The scene is a path between the river Daugava and a residential house. It is a stretch of land that is $24 \mathrm{~m}$ wide and ca. $90 \mathrm{~m}$ long. It is bordered on one side by $14 \mathrm{~m}$ high buildings. In the Figure 7 this scene is depicted as it is seen from the theroretical perspective, i.e., applying the Model of Measurements of Spatial Aesthetics. Here the space is measured from wall of the house until the slope. The space is evaluated as enclosed, disliked scene with one mystery element and no legibility.

Figure 8 shows the size of the scene as it appeared in the interviews. In relationship to the evaluation by visual analysis method, the new space appears to be much larger. The interviewees talk about "the water and nature" that form the space. It extends until the opposite bank and is much longer than $90 \mathrm{~m}$, it virtually extends as far as one can see, as can be detected from the interviews. Everyone loves the space, hence, the field that demarcates it in the figure 8 is of a light color. Again, also here no interviewee speaks of mystery and legibility in a direct form.

Figure 9 shows the scene as it is comprehended by the researcher. Using the expert knowledge and interpreting such an objects as the river in order to find legibility and mystery, a very different characterization of the setting in relationship to the visual analysis is appearing. The river is forming a meander, which gives the scene a very powerful element of mystery. Also, the slope leading from the path to the river is an element(s) of mystery, since descending it one acquires an overview of a setting that cannot be seen from above - from the path. The water also offers an inexhaustible amount of legibility. One can hide in the water. Besides that, if one swims couple of meters a very different scene appears as from the current stand point.

Thus the scene receives uncountable points of mystery and more than eternity points of legibility. It is highly preferred as mentioned by the inhabitants. The mystery point formed by the walls of the house (Figure 8) hypothetically adds up to the mystery level. The assumption can be done: a large open, undefined space that the scene turns out to be is "improved" with sufficient amount of mystery and legibility amounts, it can become very liked in reality.

So called expert visual investigation was used to find and analyse the information "hidden in the 
interviews" on legibility and mystery elements of urban spaces. This investigation was based on inhabitant interviews in situ, but used expert knowledge to decipher the information of these elements. The interviews, that were discursively analyzed prior to using expert visual investigation method, provided information on size and preferability of spaces in question.

Both methods - discursive interview analysis and expert visual analysis - together provide information on three issues of interest: size, preference and mystery and legibility elements. Two data collection procedures from the same material - interviews - is proving that mixed method usage in dealing with testing theoretical questions on spatial aesthetics is recommended.

\section{Conclusion}

Spatial aesthetics is a complex issue as the theories of environmental psychology on it are. Some of the issues of interest to the researcher are evidently of such a theoretical nature that there is no lay-man that can speak of them on their own initiative.

Mixed method is a legitimate tool that enriches the research. In the case of our paper it helps to test the theory on spatial aesthetics. Yet, the downsides of such a mixed method have to be addressed in a separate paper.

\section{References}

1. Alkhresheh, M. M. Enclosure as a Function of Height-to-Width Ratio and Scale: Its Influence on Users's Sense of Comfort and Safety in Urban Street Space. PhD Thesis. Gainesville: University of Florida, 2007. 190 p.

2. Creswell J. W. A Concise Introduction to Mixed Methods Research. Thousand Oaks: Sage Publications, 2014 , p. 152.

3. Fusch, P. I., Ness, L. R. Are We There Yet? Data Saturation in Qualitative Research. Qualitative Report, 2015, Vol. 20, p. $1408-1416$.

4. Guest G., Bunce A., Johnson L. How many interviews are enough? An experiment with data saturation and variability. Field Methods, 2006, Vol. 18, p. 59-82.

5. Herzog T. R., Maguire P., Nebel M. B. Assessing the restorative components of environment. Journal of Environmental Psychology, 2003, Vol. 23, p. 159-170.

6. Heerwagen, J. The psychological aspects of windows and window design. In: Anthony, K.H., Choi, J., Orland B. (Eds.), Proceedings of the 21st Annual Conference of the Environmental Design Research Association. EDRA, Oklahoma City, 1990, p. 269-280.

7. Hildebrand, G. Origins of Architectural Pleasure. Barkley: University of California Press, 1999, p. 174.

8. Kaplan, S. Concerning the Power of Content-identifying Methodologies. In: Daniel T. C., Zube, E. H. (eds.) Assessing Amenity Resource Values. USDA Forest Service General Technical Report RM-68. Fort Collins: Rocky Mountain Forest and Range Experimental Station, 1979a, 35 p.

9. Kusmane, A.S., How to Measure the Impact of Spatial Aesthetics on the Everyday in Soviet Housing Estates? Landscape Architecture and Art: scientific journal of Latvia University of Life Sciences and Technologies. Jelgava: LLU, 2016, Vol. 9., p. 7-20.

10. Kusmane A.S., İle U., Importance of Landscape elements in perception of Spatial Aesthetcis in Residential Areas. Research for Rural Development: international scientific conference proceedings. Jelgava, LLU, 2017, Vol, 1, p. 187-194.

11. O'Neill, M. J., Evaluation of a Conceptual Model of Architectural Legibility. Environment and Behavior, 1991, Vol. 23, p. $259-284$.

12. Orford S, Webb B., Mapping the interview transcript: identifying spatial policy areas from daily working practices. Area, 2017, p. 1-11.

13. Stamps, A. E. Enclosure and Safety in Urban Spaces. Environment and Behavior, 2005, Vol. 37, p. 102-132.

14. Tashakkori, A., Creswell J.W., Editorial: The New Era of Mixed Method. Journal of Mixed Methods Research, 2007, Vol.3, p. 1-7.

15. Thompson P. The Voice of the Past: Oral History. Oxford: Oxford University Press, 1988, p. 196.

16. Weisman, J., Evaluating Architectural Legibility: Way-finding in the Built Environment, Environment and Behavior, 1981, Vol. 13(2), p.189- 204.

\section{INFORMATION ABOUT AUTHOR:}

Agnese Sofija Kusmane is a doctoral student of landscape architecture at Latvia University of Life Sciences and Technologies. She is interested in relationship between spatial aesthetics and behaviour.

Kopsavilkums. Raksta mērķis ir aprakstīt metodi, kura, vienkopus ar jau izmantoto kvalitatīvo interviju pielietojumu, testē telpiskās estētikas teoriju. Minētā teorija balstās evolucionāras estētikas pieñēmumos. Tā postulē, ka dabā pastāv četras telpiskās kategorijas, katrai no šīm kategorijām ir atškirīgi izmērs un proporcijas. Ainavas elementi mistika un salasāmība, esot pietiekamā daudzumā, teorētiski var uzlabot šo iecienītības līmeni.

Kā liecina literatūra, vispiemērotākais veids teorijas pārbaudīšanai ir daḷēji strukturētas intervijas. Ar to palīdzību iegūtā informācija par telpas estētiku, potenciāli paplašina un dekonstruē teorētisko ietvaru, kurā aprakstītā teorija balstās. Lai to veiktu, tikai veiktas in situ intervijas ar triju Rīgas dzīvojamo rajonu iedzīvotājiem. Interviju mērḳis bija pārbaudīt telpiskās estētikas teorijas trijos būtiskajos punktos: uztvertās telpas lielumu, telpas iecienītību, kā arī mistikas un salasāmības elementu klātbūtni telpā. 
Pilotpētījums rādīja, ka intervijas sniedza pietiekami daudz informācijas pirmo divu punktu analīzei. Tomēr trešā punkta izvērtēšanai informācijas pietrūka. Lai novērstu šo nepilnību, tika izmantota papildus metode: eksperta vizuālā izpēte. Pētījumā metode tiek izmantota kā papildinājums jau iepriekš veiktajai interviju diskursa analīzei. Eksperta vizuālā analīze paredz, ka pētnieks izskata intervijās minētos telpu veidojošos objektus tādā veidā, kas sniedz norādījumus par salasāmības un mistikas elementu klātbūtni.

Raksts ierosināts izmantot t.s. jaukto metodi (mixed method), lai veiksmīgi izzinātu telpas estētikai veltīto teoriju atbilstību realitātei. 